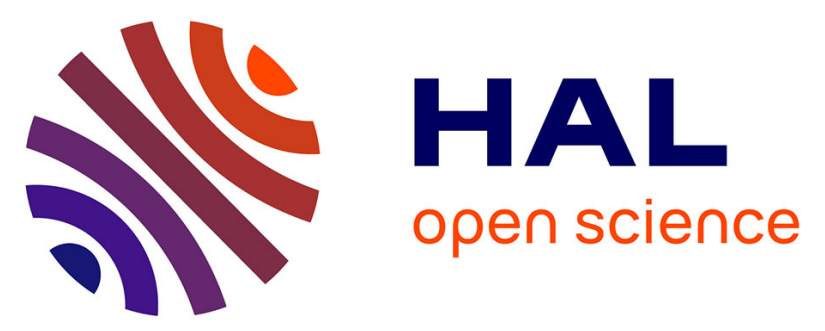

\title{
Sedimentary processes in the Thau Lagoon (France): From seasonal to century time scales
}

Sabine Schmidt, Jean-Marie Jouanneau, Olivier Weber, Pascal Lecroart, Olivier Radakovitch, Franck Gilbert, Didier Jézéquel

\section{To cite this version:}

Sabine Schmidt, Jean-Marie Jouanneau, Olivier Weber, Pascal Lecroart, Olivier Radakovitch, et al.. Sedimentary processes in the Thau Lagoon (France): From seasonal to century time scales. Estuarine, Coastal and Shelf Science, 2007, 72, pp.534-542. 10.1016/j.ecss.2006.11.019 . hal-00315640

\section{HAL Id: hal-00315640 \\ https://hal.science/hal-00315640}

Submitted on 5 Jun 2013

HAL is a multi-disciplinary open access archive for the deposit and dissemination of scientific research documents, whether they are published or not. The documents may come from teaching and research institutions in France or abroad, or from public or private research centers.
L'archive ouverte pluridisciplinaire HAL, est destinée au dépôt et à la diffusion de documents scientifiques de niveau recherche, publiés ou non, émanant des établissements d'enseignement et de recherche français ou étrangers, des laboratoires publics ou privés. 


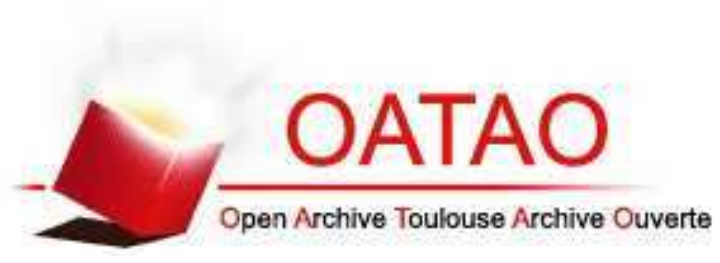

\section{Open Archive Toulouse Archive Ouverte (OATAO)}

OATAO is an open access repository that collects the work of Toulouse researchers and makes it freely available over the web where possible.

This is an author-deposited version published in: http://oatao.univ-toulouse.fr/ Eprints ID: 6093

To link to this article: DOI: 10.1016/j.ecss.2006.11.019

URL: http://dx.doi.org/10.1016/j.ecss.2006.11.019

To cite this version: Schmidt, Sabine and Jouanneau, Jean-Marie and Weber, Olivier and Lecroart, Pascal and Radakovitch, Olivier and Gilbert, Franck and Jézéquel, Didier Sedimentary processes in the Thau Lagoon (France): From seasonal to century time scales. (2007) Estuarine, Coastal and Shelf Science, vol. $72\left(\mathrm{n}^{\circ} 3\right)$. pp. 534-542. ISSN 0272-7714

Any correspondence concerning this service should be sent to the repository administrator: staff-oatao@ listes.diff.inp-toulouse.fr 


\title{
Sedimentary processes in the Thau Lagoon (France): From seasonal to century time scales
}

\author{
Sabine Schmidt ${ }^{\text {a**, Jean-Marie Jouanneau }}{ }^{\text {a }}$, Olivier Weber ${ }^{\text {a }}$, Pascal Lecroart ${ }^{\text {a }}$, \\ Olivier Radakovitch $^{\mathrm{b}}$, Franck Gilbert $^{\mathrm{c}}$, Didier Jézéquel ${ }^{\mathrm{d}}$ \\ a Département de Géologie et d'Océanographie, UMR5805 EPOC, Université Bordeaux 1, Avenue des Facultés, 33405 Talence Cedex, France \\ ${ }^{\mathrm{b}}$ UMR6635 CEREGE, Europole de l'Arbois, 13540 Aix-en-Provence, France \\ ${ }^{\mathrm{c}}$ UMR6117, LMGEM, COM, Campus de Luminy, 13288 Marseille Cedex 9, France \\ ${ }^{\mathrm{d}}$ UMR7047 LGE, 75251 Paris Cedex 05, France
}

\begin{abstract}
As a part of the MICROBENT programme, an investigation of the sedimentation framework was carried out at the water-sediment interface in the Thau Lagoon (French Mediterranean coast). Two main sites, C4 in the middle of the lagoon and C5 near oyster farms, were visited six times between December 2001 and May 2003. Interface sediments were studied using classical sedimentology parameters (radiography RX, grain size distribution) and analysis of selected radionuclides $\left({ }^{234} \mathrm{Th},{ }^{7} \mathrm{Be},{ }^{210} \mathrm{~Pb},{ }^{226} \mathrm{Ra}\right)$. On a century time scale, excess ${ }^{210} \mathrm{~Pb}\left({ }^{210} \mathrm{~Pb}\right.$ xs $)$ presents classical profiles with an upper mixed layer, followed by an exponential decrease of activities to undetectable levels below $20-30 \mathrm{~cm}$. At the central site, $\mathrm{C} 4$, cores seem to register episodic changes in mean grain size, presenting recurrently peaks. The upper $10 \mathrm{~cm}$ of ${ }^{210} \mathrm{~Pb} \mathrm{xs}_{\mathrm{x}}$ profiles at site C5 exhibit a mixed layer associated with coarser sediments: this could be related to biological activity. Sedimentation rates derived from ${ }^{210} \mathrm{~Pb}_{\mathrm{xs}}$ varied from $0.15 \mathrm{~cm} \mathrm{y}^{-1}$ at the edge of the basin, to $0.25 \mathrm{~cm} \mathrm{y}^{-1}$ at the central site. On a seasonal time scale, ${ }^{234} \mathrm{Th}$ and ${ }^{7} \mathrm{Be}$ both show significant variations in activities and in penetration within the sediment. Bioturbation rates derived from both radionuclides agree well and range between $1-10 \mathrm{~cm}^{2} \mathrm{y}^{-1}$ at site $\mathrm{C} 4$ and $1-31 \mathrm{~cm}^{2} \mathrm{y}^{-1}$ at site $\mathrm{C} 5 .{ }^{234} \mathrm{Th}$ and ${ }^{7} \mathrm{Be}$ fluxes at the water-sediment interface show too seasonal variations, more pronounced for site $\mathrm{C} 5$. This latter site presents especially a higher variability that is well marked with season, probably in relation with its position near oyster farms.
\end{abstract}

\section{Introduction}

Coastal areas, as the land-ocean interface, are the place of ultimate transformations (i.e. remineralisation, diagenesis, storage) of anthropogenic inputs from agricultural, domestic and industrial origins. Chronologies of contaminant input are dependent on the ability to establish the depositional history of the sediment (Fuller et al., 1999). In such context,

\footnotetext{
* Corresponding author.

E-mail address: s.schmidt@epoc.u-bordeaux1.fr (S. Schmidt).
}

determination of sedimentation rates is an important aspect of biogeochemical investigations in coastal waters.

Sediment accumulation rates have been widely determined in nearshore environments using radiometric and chemical methods, involving the identification of one or more elements whose inputs are known and which, once deposited, are immobile in the sediment column (Appleby and Oldfield, 1992). Radionuclides such as ${ }^{234} \mathrm{Th},{ }^{210} \mathrm{~Pb}$ or ${ }^{137} \mathrm{Cs}$ have been often used, during the last two decades, as chronometers for estimating accumulation and mixing rates in marine and lake sediments (Koide et al., 1973; Robbins and Edgington, 1975; Cochran and Aller, 1979; Sharma et al., 1987). The 
distribution of a particle-reactive radionuclide in a sediment column can result from either simple sediment accumulation or bioturbation plus sediment accumulation (DeMaster et al., 1985). The effects can be resolved using radionuclides with different half-life. The ${ }^{210} \mathrm{~Pb}$ method gives an average accumulation rate for the past 100 years while ${ }^{234} \mathrm{Th}$ and ${ }^{7} \mathrm{Be}$ are applicable for the last past 3 months.

The present work is a part of the PNEC MICROBENT programme, which focuses on the exchange between the water column and sediments (Rabouille et al., 2007). In order to assess such processes, a better knowledge of the sedimentation processes (sedimentation, bioturbation) is required, as a crucial prerequisite to calculate fluxes, and thus to allow comparison between sites. Therefore we investigated sedimentation processes, from seasonal to century time scales, at the watersediment interface in the Thau Lagoon (South France). We report here detailed depth profiles of the particle-reactive radionuclides ${ }^{210} \mathrm{~Pb}$ (22.1 years), ${ }^{7} \mathrm{Be}$ (53.3 days) and ${ }^{234} \mathrm{Th}(24.1$ days) in sediment cores collected at different seasons. These data, combined with granulometry and RX imagery, are interpreted in order to provide bioturbation and sediment accumulation rates for the Thau Lagoon.

\section{Methods}

\subsection{Study site}

The Thau Lagoon is located on the French Mediterranean coast (Fig. 1). This shallow basin of a mean depth of $4.5 \mathrm{~m}$ and about $70 \mathrm{~km}^{2}$ area is almost closed with only narrow openings to the Mediterranean Sea. This ecosystem is of

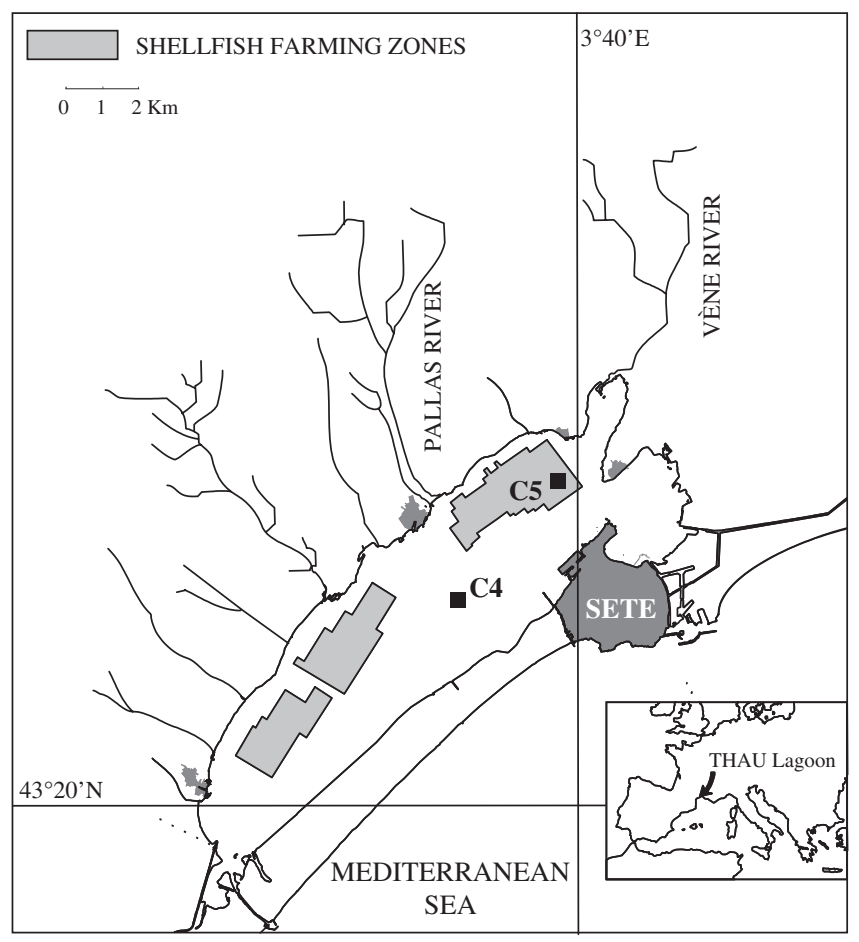

Fig. 1. Map of the Thau Lagoon. notable interest related to economic activities: shellfish production, tourism and industry (Labonne et al., 2001; Plus et al., 2003). In particular the Thau Lagoon is the main regional site of oyster cultivation with about 15,000 tons per year, i.e. roughly $10 \%$ of the national production (Gangnery et al., 2001). But the Thau Lagoon is regularly affected, usually in summer, by anoxic crises, known as malaïgues, which could induce shellfish mortality (Chapelle et al., 2000).

\subsection{Sampling and analysis}

Repeated field campaigns allowed detailed sampling of interface sediments in December 2001, April, July and August 2002, January and May 2003. Sediment cores were taken by scuba divers using hand-driven tubes. For the purpose of this study, two different sets of samples were necessary. The first one consisted of long cores, up to $50 \mathrm{~cm}$ in length, to constrain long-term sedimentation. At the lab, these cores (C4-A, C4-B, C4-D, C5-B) were opened, described, photographed, sliced longitudinally for radiographical study and sampled each centimetre for granulometry analyses. Radiographic imaging was performed with a classical X-ray equipment (SCOPIX) coupled with CEGELEC radioscopy instrumentation (Migeon et al., 1998). This technique, relatively inexpensive, fast and easy to handle, is used to identify sedimentary structures and textures (presence of reworking by burrowing organisms, consolidated or unconsolidated sediment, change in grain size). It helped in the selection of layers for ${ }^{210} \mathrm{~Pb}$ and ${ }^{226} \mathrm{Ra}$ analyses. The sediment was dried at $60{ }^{\circ} \mathrm{C}$, gently homogenized and sieved at $63 \mu \mathrm{m}$, prior to radionuclide analysis. These measurements were made at the EPOC-DGO using a semi-planar germanium detector (EGSP 2200-25-R, EURYSIS Measures) (Jouanneau et al., 2002). ${ }^{210} \mathrm{~Pb}$ in excess of equilibrium with ${ }^{226} \mathrm{Ra},{ }^{210} \mathrm{~Pb}_{\mathrm{xs}}$, was calculated as the difference between measured ${ }^{210} \mathrm{~Pb}$ and ${ }^{226} \mathrm{Ra}$. Two additional cores (C4-C, C5-C) were upward extruded and sliced in $1 \mathrm{~cm}$ increments. ${ }^{210} \mathrm{~Pb}$ activities were measured at CEREGE on these samples by $\alpha$ spectrometry after sediment digestion (Radakovitch et al., 1999). Total ${ }^{210} \mathrm{~Pb}$ activities determined by $\alpha$ spectrometry are consistent with those determined by $\gamma$ spectrometry.

The second set of cores consisted of short cores, less than $20 \mathrm{~cm}$ in length, taken to investigate short-term sedimentation. Immediately after retrieval, cores were carefully extruded each $0.5 \mathrm{~cm}$. Back in the laboratory, sediment samples were sieved at $63 \mu \mathrm{m}$ and dried at $60{ }^{\circ} \mathrm{C}$. Then the uppermost sediment layers were measured at the LSCE for ${ }^{234} \mathrm{Th}$ and ${ }^{7} \mathrm{Be}$ determinations using a low background-high efficiency well type $\gamma$-detector (Schmidt et al., 2001). These measurements had to be completed within one month after sampling, due to the rapid decay of ${ }^{234} \mathrm{Th}$. Sediment layers were investigated downcore until a rather constant ${ }^{234} \mathrm{Th}$ activity was reached, which was considered as the supported activity, and the disappearance of ${ }^{7} \mathrm{Be} .{ }^{238} \mathrm{U}$ activities were determined by $\alpha$ counting after sediment digestion by a mixture of $\mathrm{HF}-\mathrm{HNO}_{3}-\mathrm{HClO}_{4}$ in presence of ${ }^{232} \mathrm{U}$ (Schmidt, 2004). Excess ${ }^{234} \mathrm{Th}$ data were calculated by subtracting the activity supported by its parent isotope, ${ }^{238} \mathrm{U}$, from the total activity in the sediment, and 


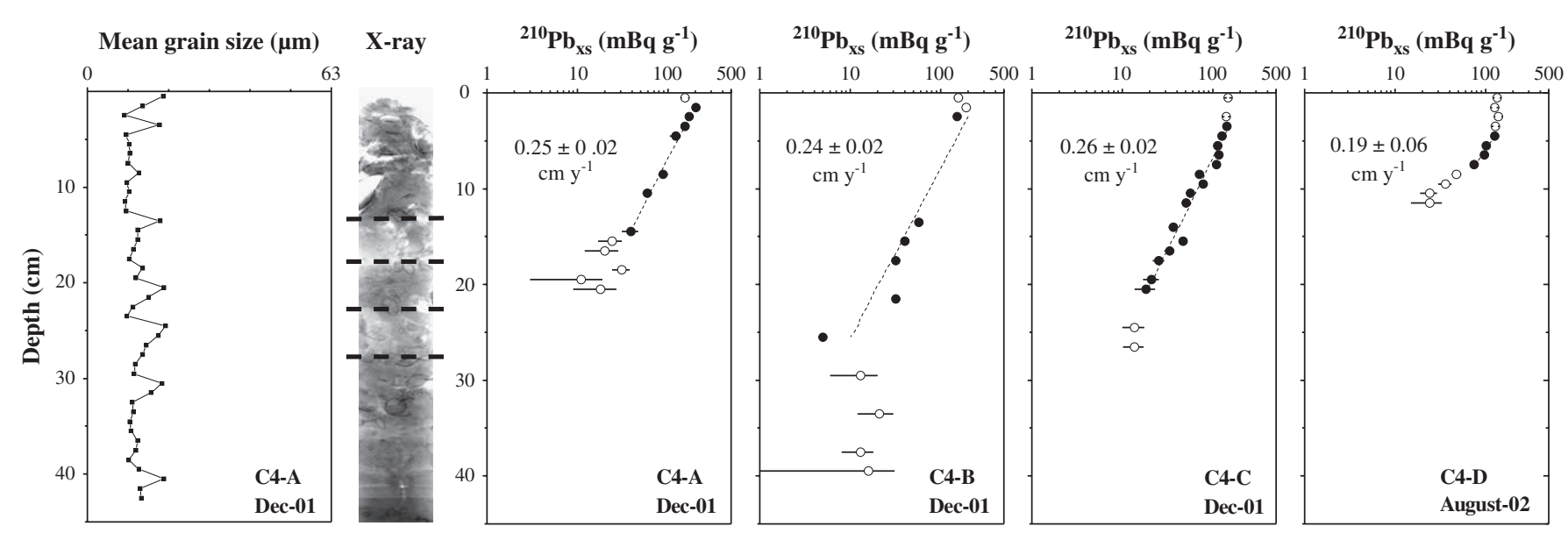

Fig. 2. X-ray, profiles of mean grain size and ${ }^{210} \mathrm{~Pb}_{\mathrm{xs}}$ for site $\mathrm{C} 4$. Sedimentation rates (and errors) were calculated using selected points of ${ }^{210} \mathrm{~Pb}_{\mathrm{xs}}$ profiles (closed symbols).

then correcting this value for radioactive decay that occurred between sample collection and counting.

\section{Results}

\subsection{Sedimentology}

The sedimentary features of the two cores observed on X-ray images and grain size curve are shown in Figs. 2 and 3. Both show roughly the same lithological facies: a grey silty clayey sediment with shells and shelly debris and without clear physical structures. Mean grain size varies between 10 and $20 \mu \mathrm{m}$. Nevertheless the density variation expressed with grey levels observed on X-ray images is quite different along the cores.

For site $\mathrm{C} 4$, core $\mathrm{C} 4-\mathrm{A}$ can be divided into several layers according to their densities with higher values between 0 and $13 \mathrm{~cm}$, from 17 to $22 \mathrm{~cm}$ and deeper than $27 \mathrm{~cm}$. In the top layer, shells are more abundant in a homogeneous clayey sediment with a mean grain size less than $10 \mu \mathrm{m}$ except for 2 samples $(0-1$ and $3-4 \mathrm{~cm})$. Core $C 4-B$ presents a disturbance of sedimentary record, a priori due to coring artefact. For site C5 (core C5-B), three sedimentary units can be distinguished. The first one corresponds to the uppermost layer, from 0 to $10 \mathrm{~cm}$, made up of a silty clayey sediment with small shells bivalves in a rich water deposit (light in grey level) indicating a very fresh sedimentary deposit where biota seems to be active. Below, from 10 to $35 \mathrm{~cm}$, the second unit is fine $(10-15 \mu \mathrm{m})$ darker and denser sediment with numerous valves of shell settled in a concave-up position.

\section{2. ${ }^{210} \mathrm{~Pb}$ profiles}

The supported ${ }^{210} \mathrm{~Pb}$ activity, i.e. ${ }^{226} \mathrm{Ra}$, is relatively homogeneous and constant at both sites with values ranging from 14 to $20 \mathrm{mBq} \mathrm{g}^{-1}$. Surface excess ${ }^{210} \mathrm{~Pb}$ levels, up to 250 $\mathrm{mBq} \mathrm{g}^{-1}$, are usual for coastal sediments (Figs. 2 and 3). Profiles of ${ }^{210} \mathrm{~Pb}_{\mathrm{xs}}$ present an upper mixed layer, followed by an exponential decrease of activities to reach supported activity

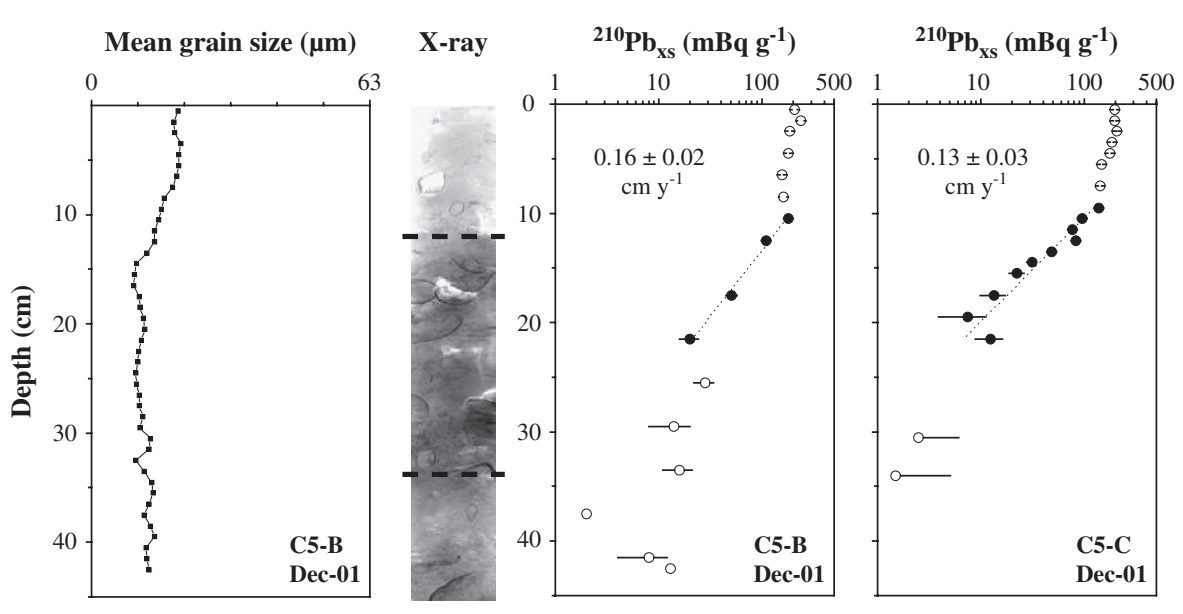

Fig. 3. Photography, X-ray, profiles of mean grain size and ${ }^{210} \mathrm{~Pb}_{\mathrm{xs}}$ for site $\mathrm{C} 5$. 
a $\underline{\text { Site } \mathbf{C 4}}$

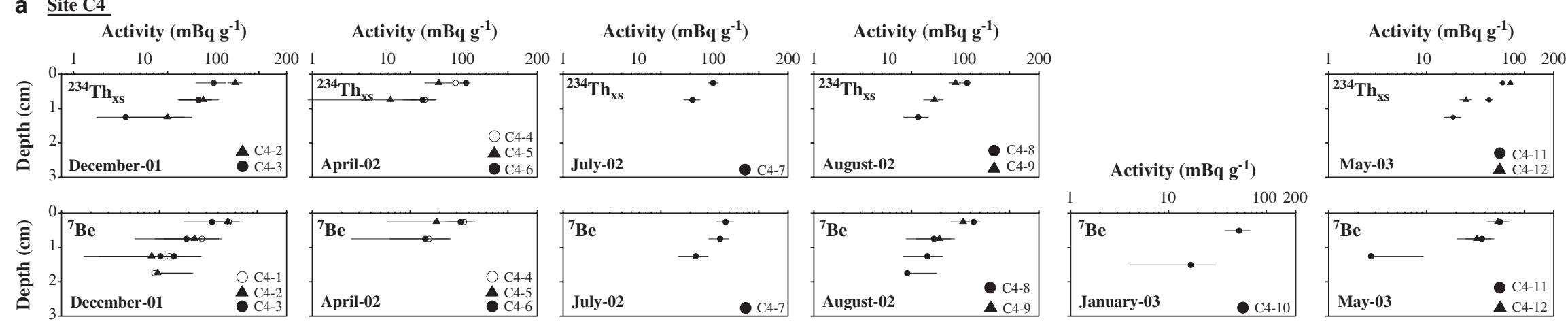

b $\underline{\text { Site } \mathrm{C5}} \quad$ Activity $\left(\mathrm{mBq} \mathrm{g}^{-1}\right) \quad$ Activity $\left(\mathrm{mBq} \mathrm{\textrm {g } ^ { - 1 }}\right) \quad$ Activity $\left(\mathrm{mBq} \mathrm{g}^{-1}\right)$

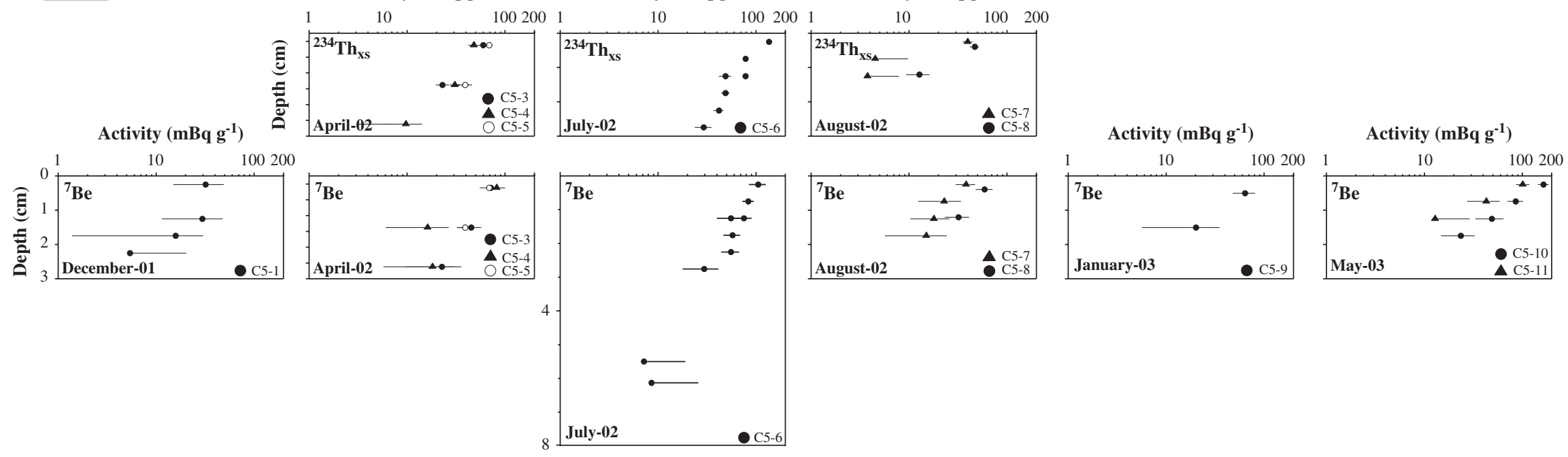

Fig. 4. Excess ${ }^{234} \mathrm{Th}$ and ${ }^{7} \mathrm{Be}$ versus depth. The upper panel (a) corresponds to site $\mathrm{C} 4$, the lower (b) to site $\mathrm{C}$. 
levels at about $20 \mathrm{~cm}$ depth. Such a feature is appropriate to the determination of sedimentation rates.

At site $\mathrm{C} 4$, the mixed layer is restricted to the uppermost $3 \mathrm{~cm}$ of sediment. For core C4-A, the rather homogeneity of the sedimentary column, revealed by X-ray, explains the good fit of the decrease of ${ }^{210} \mathrm{~Pb}$ activities in excess. For core $\mathrm{C} 4-\mathrm{B}$, the layer around $5-10 \mathrm{~cm}$, that presents disturbance, was not sampled for radionuclide determination (Fig. 2). ${ }^{210} \mathrm{~Pb}$ profiles, measured on three different cores, matched rather well. At site $\mathrm{C} 5$, nearby oyster farming, the upper $10 \mathrm{~cm}$ of the two ${ }^{210} \mathrm{~Pb}_{\mathrm{xs}}$ profiles exhibit a wellpronounced mixed layer associated with the sequence of coarser sediment (Fig. 3). Below this surface layer, the profile shows an exponential decrease, with no evidence of strong disturbance.

\section{3. ${ }^{7}$ Be and ${ }^{234}$ Th $_{x s}$ profiles}

Uppermost activities of ${ }^{234} \mathrm{Th}_{\mathrm{xs}}$ and ${ }^{7} \mathrm{Be}$ range between 20 and $72 \mathrm{mBq} \mathrm{g}^{-1}$ at site $\mathrm{C} 4$ and between 30 and $166 \mathrm{mBq} \mathrm{g}^{-1}$ at site C5 (Fig. 4; Tables 1 and 2). These changes in activities are associated, to a lesser extent, with variations in penetration depth. Both radionuclides usually disappear within the first $2 \mathrm{~cm}$. It is noticeable that the highest activities are associated with the deepest penetration in July 2002. This latter does not exceed the mixed layer of ${ }^{210} \mathrm{~Pb}_{\mathrm{xs}}$, which provides a coherent picture of sedimentary processes; indeed ${ }^{210} \mathrm{~Pb}_{\mathrm{xs}}$, with its long half-life, registers the deepest mixed layer that was observed on short-lived radionuclides profiles. Activities of ${ }^{234} \mathrm{Th}_{\mathrm{xs}}$ are moderate when compared to previous works (Aller and Cochran, 1976; Schmidt et al., 2002). ${ }^{7}$ Be values are in the range of published values (Olsen et al., 1986). Both ${ }^{234} \mathrm{Th}$ and ${ }^{7} \mathrm{Be}$ show seasonal variations in activities and in penetration within the sediment.

\section{Discussion}

A previous study had investigated long-term sedimentation in the eastern part of the Thau Lagoon (Monna et al., 1997). The present work focuses on sedimentation from seasonal to century time scales at two sites of contrasting characteristics:

Table 1

${ }^{7} \mathrm{Be}$ and ${ }^{234} \mathrm{Th}_{\mathrm{xs}}$ activities in sediments of site C4. (n.m., time elapsed between sampling and counting too long to allow ${ }^{234} \mathrm{Th}$ determination; n.d., no detectable level of ${ }^{234} \mathrm{Th}_{\mathrm{xs}}$ )

\begin{tabular}{|c|c|c|c|c|}
\hline Date & $\begin{array}{l}\text { Core } \\
\text { (label) }\end{array}$ & $\begin{array}{l}\text { Layer } \\
(\mathrm{cm})\end{array}$ & $\begin{array}{l}{ }^{7} \mathrm{Be} \\
\left(\mathrm{mBq} \mathrm{g}^{-1}\right)\end{array}$ & $\begin{array}{l}{ }^{234} \mathrm{Th}_{\mathrm{xs}} \\
\left(\mathrm{mBqg}^{-1}\right)\end{array}$ \\
\hline \multirow[t]{12}{*}{ December 4, 2001} & \multirow[t]{4}{*}{ C4-1 } & $0.0-0.5$ & $51.6 \pm 13.8$ & n.m. \\
\hline & & $0.5-1.0$ & $27.0 \pm 15.9$ & n.m. \\
\hline & & $1.0-1.5$ & $12.6 \pm 10.9$ & n.m. \\
\hline & & $1.5-2.0$ & $8.9 \pm 13.1$ & n.m. \\
\hline & \multirow[t]{4}{*}{$\mathrm{C} 4-2$} & $0.0-0.5$ & $50.5 \pm 16.3$ & $55.3 \pm 9.8$ \\
\hline & & $0.5-1.0$ & $22.9 \pm 17.3$ & $24.7 \pm 11.6$ \\
\hline & & $1.0-1.5$ & $8.4 \pm 9.7$ & $10.1 \pm 8.4$ \\
\hline & & $1.5-2.0$ & $9.6 \pm 11.5$ & n.d. \\
\hline & \multirow[t]{4}{*}{$\mathrm{C} 4-3$} & $0.0-0.5$ & $34.8 \pm 17.1$ & $31.9 \pm 11.5$ \\
\hline & & $0.5-1.0$ & $19.1 \pm 10.1$ & $21.9 \pm 8.4$ \\
\hline & & $1.0-1.5$ & $14.1 \pm 11.7$ & $3.5 \pm 11.9$ \\
\hline & & $1.5-1.5$ & $10.3 \pm 16.5$ & n.d. \\
\hline \multirow[t]{6}{*}{ April 10, 2002} & \multirow[t]{2}{*}{$\mathrm{C} 4-4$} & $0.0-0.5$ & $35.4 \pm 10.8$ & $29.5 \pm 4.5$ \\
\hline & & $0.5-1.0$ & $15.7 \pm 9.5$ & $14.1 \pm 4.0$ \\
\hline & \multirow[t]{2}{*}{$\mathrm{C} 4-5$} & $0.0-0.5$ & $18.7 \pm 12.9$ & $19.6 \pm 5.4$ \\
\hline & & $0.5-1.0$ & $0.0 \pm 13.7$ & $6.3 \pm 5.4$ \\
\hline & \multirow[t]{2}{*}{$\mathrm{C} 4-6$} & $0.0-0.5$ & $33.0 \pm 10.0$ & $37.4 \pm 4.3$ \\
\hline & & $0.5-1.0$ & $14.3 \pm 11.8$ & $13.5 \pm 5.0$ \\
\hline \multirow[t]{4}{*}{ July 17, 2002} & \multirow[t]{4}{*}{$\mathrm{C} 4-7$} & $0.0-0.5$ & $46.1 \pm 9.4$ & $34.3 \pm 4.0$ \\
\hline & & $0.5-1.0$ & $40.2 \pm 9.2$ & $21.1 \pm 4.0$ \\
\hline & & $1.0-1.5$ & $22.1 \pm 7.7$ & n.d. \\
\hline & & $1.5-2.0$ & $0.0 \pm 6.9$ & n.d. \\
\hline \multirow[t]{6}{*}{ August 27, 2002} & \multirow[t]{4}{*}{$\mathrm{C} 4-8$} & $0.0-0.5$ & $42.8 \pm 7.2$ & $36.7 \pm 3.6$ \\
\hline & & $0.5-1.0$ & $17.0 \pm 8.2$ & $9.4 \pm 4.0$ \\
\hline & & $1.0-1.5$ & $14.5 \pm 6.3$ & $11.6 \pm 3.3$ \\
\hline & & $1.5-2.0$ & $9.0 \pm 9.1$ & $5.1 \pm 3.7$ \\
\hline & \multirow[t]{2}{*}{ C4-9 } & $0.0-0.5$ & $33.9 \pm 8.7$ & $28.1 \pm 3.9$ \\
\hline & & $0.5-1.0$ & $19.3 \pm 8.2$ & $17.2 \pm 3.9$ \\
\hline \multirow[t]{2}{*}{ January 28, 2003} & \multirow[t]{2}{*}{ C4-10 } & $0.0-1.0$ & $53.0 \pm 15.2$ & n.m. \\
\hline & & $1.0-2.0$ & $16.9 \pm 13.1$ & n.m. \\
\hline \multirow[t]{5}{*}{ May 19, 2003} & \multirow[t]{3}{*}{ C4-11 } & $0.0-0.5$ & $56.3 \pm 13.7$ & $60.1 \pm 4.2$ \\
\hline & & $0.5-1.0$ & $36.9 \pm 11.8$ & $43.8 \pm 3.9$ \\
\hline & & $1.0-1.5$ & $2.7 \pm 6.6$ & $18.7 \pm 3.7$ \\
\hline & \multirow[t]{2}{*}{ C4-12 } & $0.0-0.5$ & $54.0 \pm 13.0$ & $72.2 \pm 3.4$ \\
\hline & & $0.5-1.0$ & $32.9 \pm 12.5$ & $25.5 \pm 3.6$ \\
\hline
\end{tabular}


Table 2

${ }^{7} \mathrm{Be}$ and ${ }^{234} \mathrm{Th}_{\mathrm{xs}}$ activities in sediments of site C5. (n.m., time elapsed between sampling and counting too long to allow ${ }^{234} \mathrm{Th}$ determination; n.d., no detectable level of ${ }^{234} \mathrm{Th}_{\mathrm{xs}}$ )

\begin{tabular}{|c|c|c|c|c|}
\hline Date & $\begin{array}{l}\text { Core } \\
\text { (label) }\end{array}$ & $\begin{array}{l}\text { Layer } \\
(\mathrm{cm})\end{array}$ & $\begin{array}{l}{ }^{7} \mathrm{Be} \\
\left(\mathrm{mBq} \mathrm{g}^{-1}\right)\end{array}$ & $\begin{array}{l}{ }^{234} \mathrm{Th}_{\mathrm{xs}} \\
\left(\mathrm{mBq} \mathrm{g}^{-1}\right)\end{array}$ \\
\hline \multirow[t]{5}{*}{ December 4, 2001} & $\mathrm{C} 5-1$ & $0.0-0.5$ & $32.1 \pm 17.0$ & n.m. \\
\hline & & $0.5-1.0$ & $14.2 \pm 16.0$ & n.m. \\
\hline & & $1.0-1.5$ & $29.6 \pm 18.1$ & n.m. \\
\hline & & $1.5-2.0$ & $15.8 \pm 14.4$ & n.m. \\
\hline & & $2.0-2.5$ & $5.4 \pm 14.9$ & n.m. \\
\hline \multirow[t]{8}{*}{ April 9, 2002} & $\mathrm{C} 5-3$ & $0.0-0.5$ & $71.6 \pm 15.8$ & $59.8 \pm 5.7$ \\
\hline & & $0.5-1.0$ & $45.1 \pm 11.9$ & $23.1 \pm 3.4$ \\
\hline & & $1.0-1.5$ & $22.6 \pm 12.8$ & $2.9 \pm 4.6$ \\
\hline & $\mathrm{C} 5-4$ & $0.0-0.5$ & $83.2 \pm 16.8$ & $48.5 \pm 5.9$ \\
\hline & & $0.5-1.0$ & $16.3 \pm 10.2$ & $30.8 \pm 3.5$ \\
\hline & & $1.0-1.5$ & $18.2 \pm 12.4$ & $9.8 \pm 4.3$ \\
\hline & $\mathrm{C} 5-5$ & $0.0-0.5$ & $66.9 \pm 12.1$ & $69.4 \pm 5.4$ \\
\hline & & $0.5-1.0$ & $43.4 \pm 18.0$ & $39.2 \pm 6.5$ \\
\hline \multirow[t]{9}{*}{ July 17,2002} & $\mathrm{C} 5-6$ & $0.0-0.5$ & $105.3 \pm 20.5$ & $136.0 \pm 8.2$ \\
\hline & & $0.5-1.0$ & $83.9 \pm 11.3$ & $78.4 \pm 4.3$ \\
\hline & & $1.0-1.5$ & $55.4 \pm 15.4$ & $48.9 \pm 7.0$ \\
\hline & & $1.0-1.5$ & $75.2 \pm 14.9$ & $78.6 \pm 5.7$ \\
\hline & & $1.5-2.0$ & $57.8 \pm 11.1$ & $48.9 \pm 4.6$ \\
\hline & & $2.0-2.5$ & $55.8 \pm 11.7$ & $41.8 \pm 4.8$ \\
\hline & & $2.5-3.0$ & $29.6 \pm 11.7$ & $29.4 \pm 5.5$ \\
\hline & & $5.0-6.0$ & $7.2 \pm 11.7$ & n.d. \\
\hline & & $7.0-8.0$ & $8.6 \pm 17.2$ & n.d. \\
\hline \multirow[t]{5}{*}{ August 28, 2003} & $\mathrm{C} 5-7$ & $0.0-0.5$ & $38.5 \pm 8.3$ & $39.8 \pm 4.2$ \\
\hline & & $0.5-1.0$ & $23.1 \pm 10.7$ & $4.5 \pm 5.3$ \\
\hline & & $1.0-1.5$ & $18.1 \pm 7.7$ & $3.8 \pm 4.0$ \\
\hline & $\mathrm{C} 5-8$ & $0.0-0.8$ & $59.5 \pm 11.1$ & $46.9 \pm 4.7$ \\
\hline & & $0.8-1.5$ & $32.1 \pm 8.7$ & $12.7 \pm 3.3$ \\
\hline \multirow[t]{2}{*}{ January 28, 2003} & $\mathrm{C} 5-9$ & $0.0-1.0$ & $64.4 \pm 15.9$ & n.m. \\
\hline & & $1.0-2.0$ & $20.3 \pm 14.6$ & n.m. \\
\hline \multirow[t]{7}{*}{ May 20, 2003} & C5-10 & $0.0-0.5$ & $165.9 \pm 19.8$ & n.m. \\
\hline & & $0.5-1.0$ & $86.4 \pm 15.5$ & n.m. \\
\hline & & $1.0-1.5$ & $48.7 \pm 15.2$ & n.m. \\
\hline & & $1.5-2.0$ & $23.7 \pm 8.9$ & n.m. \\
\hline & C5-11 & $0.0-0.5$ & $102.0 \pm 15.3$ & n.m. \\
\hline & & $0.5-1.0$ & $42.9 \pm 15.4$ & n.m. \\
\hline & & $1.0-1.5$ & $12.9 \pm 16.2$ & n.m. \\
\hline
\end{tabular}

C4 in the middle of the lagoon (8 $\mathrm{m}$ depth) and C5 near oyster farms (9 m depth) (Fig. 1).

\subsection{Sediment accumulation rates derived from ${ }^{210} \mathrm{~Pb}$}

The ${ }^{210} \mathrm{~Pb}$ method is based on the measurement of the excess or unsupported activity ${ }^{210} \mathrm{~Pb}$, which is incorporated rapidly into the sediment from atmospheric fallout and water column scavenging (Appleby and Oldfield, 1992). Once incorporated into the sediment, unsupported ${ }^{210} \mathrm{~Pb}$ decays with depth, equivalent to time, in the sediment column according to its known half-life. In applying this principle, it is assumed that the specific activity of newly deposited particles at a given site is constant with time. Therefore, sediment accumulation rate can be derived from ${ }^{210} \mathrm{~Pb}$, based on two assumptions: constant flux and constant sediment accumulation rate (CF:CS method) (Krishnaswamy et al., 1971; Robbins and Edgington, 1975). Then, assuming no mixing at depth, the decrease of ${ }^{210} \mathrm{~Pb}_{\mathrm{xs}}$ activities with depth is described by the following relation: $\left[{ }^{210} \mathrm{~Pb}_{\mathrm{xs}}\right]_{z}=\left[{ }^{210} \mathrm{~Pb}_{\mathrm{xs}}\right]_{0} \exp [-\lambda z / S]$

where $\left[{ }^{210} \mathrm{~Pb}_{\mathrm{xs}}\right]_{0}$ and $\left[{ }^{210} \mathrm{~Pb}_{\mathrm{xs}}\right]_{\mathrm{z}}$, in $\mathrm{mBq} \mathrm{g}^{-1}$, are the activities of excess ${ }^{210} \mathrm{~Pb}$ at surface (or base of the mixed layer) and at depth $z$ respectively, $\lambda\left(\mathrm{y}^{-1}\right)$ is the decay constant of the nuclide, and $S\left(\mathrm{~cm} \mathrm{y}^{-1}\right)$ is the sediment accumulation rate.

We applied this method to the profiles obtained at both sites $\mathrm{C} 4$ and $\mathrm{C} 5$. For site $\mathrm{C} 4$, sedimentation rates determined on three different cores collected in December 2001 present a reduced range: $0.25,0.24$ and $0.26 \mathrm{~cm} \mathrm{y}^{-1}$ (Fig. 2). The single core collected in August 2002 leads to a slightly lower and less precise estimate $\left(0.19 \mathrm{~cm} \mathrm{y}^{-1}\right)$. With a measured dry bulk density (DBD) of about $0.5 \mathrm{~g}$ per $\mathrm{cm}^{3}$, mass accumulation rate at $\mathrm{C} 4$ is about $0.12 \mathrm{~g} \mathrm{~cm}^{-2} \mathrm{y}^{-1}$, comparable to the value of $0.11 \mathrm{~g} \mathrm{~cm}^{-2} \mathrm{y}^{-1}\left(0.22 \mathrm{~cm} \mathrm{y}^{-1}\right.$ from ${ }^{210} \mathrm{~Pb}_{\mathrm{xs}}$ profile $)$ previously published by Monna et al. (1997). For site C5, sedimentation rates, calculated below the thick mixed layer, is in good agreement between the two studied cores: 0.13 
and $0.16 \mathrm{~cm} \mathrm{y}^{-1}$, or around $0.05 \mathrm{~g} \mathrm{~cm}^{-2} \mathrm{y}^{-1}$ with a DBD of $0.3 \mathrm{~g} \mathrm{~cm}^{-3}$ (Fig. 3).

Spatial distributions of bottom stress and of fine fraction $(<63 \mu \mathrm{m})$ in surface sediments clearly point out the central part of the Thau Lagoon as the preferential site for sedimentation (Millot, 1989; Pena, 1989). The present results agree well with this general frame and, not surprisingly, site C4 presents the highest sedimentation rate, when compared to site $\mathrm{C} 5$.

\subsection{Bioturbation rates and radionuclide fluxes}

Taking into account their short half-lives and the sedimentation rates derived from ${ }^{210} \mathrm{~Pb}(0.15-0.25 \mathrm{~cm}$ per year), ${ }^{234} \mathrm{Th}_{\mathrm{xs}}$ and ${ }^{7} \mathrm{Be}$ should be present only at the water-sediment interface. However all the profiles show penetration of both short-lived radionuclides to variable depths that indicates efficient mixing of upper sediments, usually referred as bioturbation. The simplest way to derive mixing rates $\left(D_{\mathrm{b}}\right)$ from radionuclide profiles assumes bioturbation as a diffusive process occurring at a constant rate within a surface mixed layer under steady-state (Fig. 5):

$D_{\mathrm{b}-\mathrm{SS}} \frac{\partial^{2} A}{\partial z^{2}}-w \frac{\partial A}{\partial z}-\lambda A=0$

Such a steady-state approximation, often used to derive bioturbation rates from radionuclide profiles, introduces only limited errors (Lecroart et al., 2007). When several cores were recovered for on the same date, there is rather good reproducibility of profiles and therefore of bioturbation rates. Indeed variability of $D_{\mathrm{b}}$ estimates is on the same order than the error induced by steady state assumption used to derive this parameter from radionuclide profiles. Such a result highlights the robustness of these estimates, even based on few points. Moreover, whatever ${ }^{234} \mathrm{Th}$ or ${ }^{7} \mathrm{Be}$ is chosen to calculate bioturbation rates, they are given comparable results (Fig. 5). This is not surprising since both radionuclides, carried to sediment by fine particles, have half-life of comparable time scale. Mixing rates obtained in the Thau Lagoon are in the lower range of reported values for coastal environment (Fuller et al., 1999; Widdows et al., 2004). For site C4, steady-state bioturbation rates range between 1 and $11 \mathrm{~cm}^{2} \mathrm{y}^{-1}$, with a weak seasonal signal. The mixing of surface sediments at site C5 presents a greater range $\left(1-32 \mathrm{~cm}^{2} \mathrm{y}^{-1}\right)$, with the highest values observed in summer. Using fluorescent particulate tracers (luminophores), Duport et al (2007) also recorded an increase in sediment mixing at both sites in August.

At steady-state, equation (2) can be analytically solved using classical boundary conditions to calculate radionuclide flux at the sediment-water interface using a least-square fit and $D_{\mathrm{b}}$ (Lecroart et al., 2007). Fluxes of ${ }^{7} \mathrm{Be}$ at the sediment-water interface obtained in the Thau lagoon range between 1.5 and $4.2 \mathrm{~Bq} \mathrm{~m}^{-2}$ day $^{-1}$ for site $\mathrm{C} 4$ and between 3.2 and $14.4 \mathrm{~Bq} \mathrm{~m}^{-2} \mathrm{day}^{-1}$ for site C5 (Fig. 5), consistent with previously published values for coastal environments (Olsen et al., 1986). Range of ${ }^{234}$ Th fluxes shows the same trend with highest values reported for site C5 (Fig. 5). Site C5 presents always a higher variability, in bioturbation rates and fluxes, when compared to site $\mathrm{C} 4$. This could be explained by the proximity of shellfish farms: the high concentration of shellfishes might lead to enhance deposition. A same impact of oyster farming is clearly identified on oxygen fluxes with
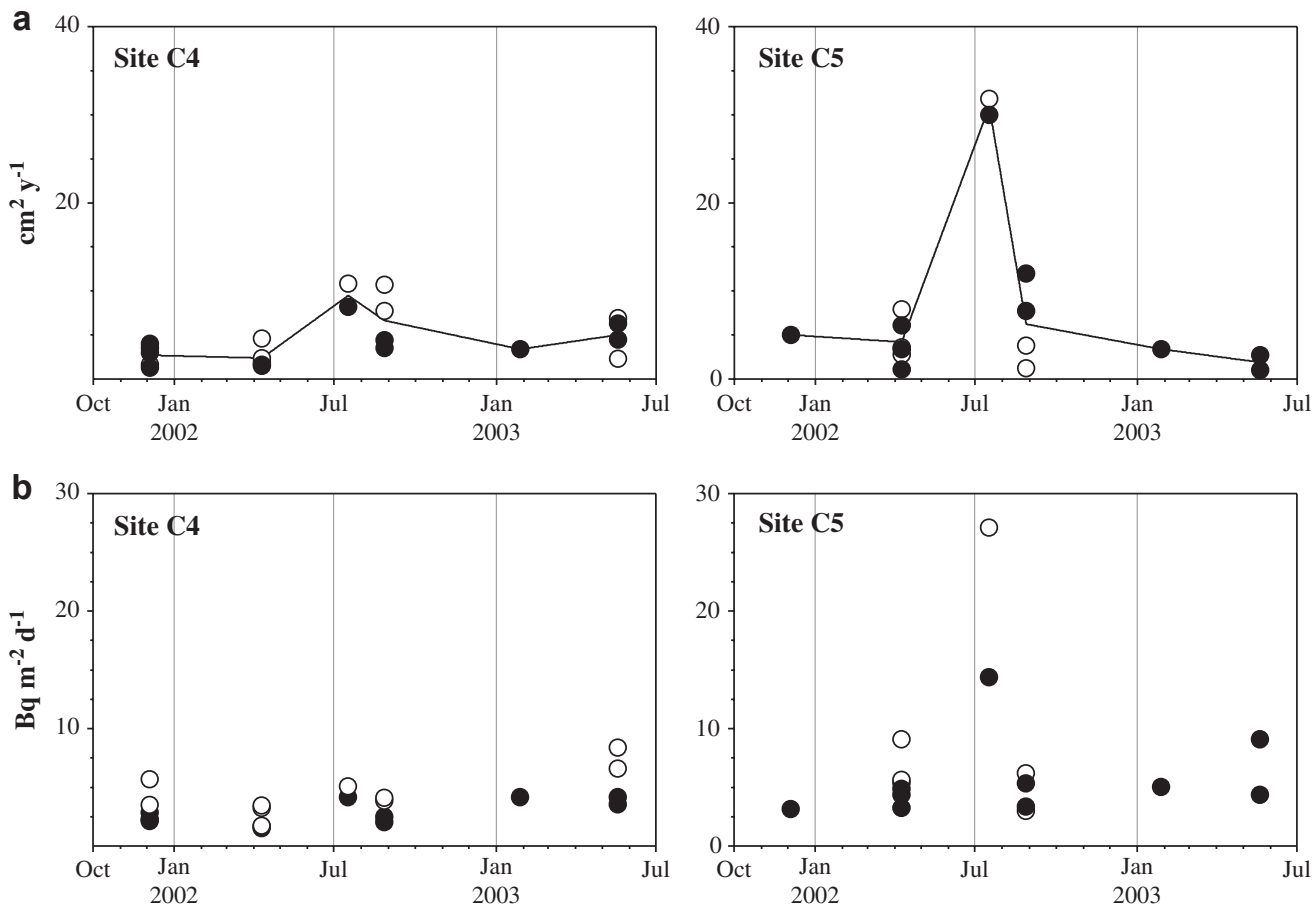

Fig. 5. Seasonal trend in (a) bioturbation rates, $\mathrm{D}_{\mathrm{b}}$, derived from ${ }^{7} \mathrm{Be}$ (closed circle) and ${ }^{234} \mathrm{Th}_{\mathrm{xs}}$ (open circle), (b) ${ }^{7} \mathrm{Be}\left(\mathrm{closed}\right.$ circle) and ${ }^{234} \mathrm{Th} \mathrm{xs}_{\mathrm{s}}$ (open circle) fluxes for sites $\mathrm{C} 4$ and $\mathrm{C} 5$. 
higher diffusive oxygen uptake in the station inside the oyster parks (C5) compared to the station outside the oyster parks (C4) (Dedieu et al., 2007).

\section{Conclusion}

This study clearly illustrates the interest of combining sedimentological parameters and radionuclides of different inputs and half-lives to describe in details processes like sediment accumulation, bioturbation, erosion / deposition at different time scales. This investigation of interface sediments provides a coherent picture of sedimentation patterns of the Thau Lagoon.

On a seasonal time scale, ${ }^{234} \mathrm{Th}$ and ${ }^{7} \mathrm{Be}$ profiles show seasonal variations in activities and in penetration within the sediment, indicating changes in mixing intensities and radionuclide fluxes. As these radionuclides are mainly carried by the fine particles, such variations must also reflected associated variations of silt content of surface sediments. ${ }^{234} \mathrm{Th}$ and ${ }^{7} \mathrm{Be}$ profiles at site $\mathrm{C} 5$ indicate a greater variability in particle accumulation, likely in relation with its position near shellfish farming. On a century time scale, ${ }^{210} \mathrm{~Pb}$ profiles indicate well-defined sedimentation rates at both sites: around 0.25 and $0.15 \mathrm{~cm} \mathrm{y}^{-1}$ for sites $\mathrm{C} 4$ and $\mathrm{C} 5$, respectively.

It is noticeable that sedimentation rates are slightly higher in the central part of the Thau (site C4), although site C5 presents seasonally enhanced particle fluxes. Such result is not contradictory: fine sediment accumulation is a balance between deposition (settling, bioaccumulation) and erosion (waves, human activity). ${ }^{210} \mathrm{~Pb}$ method integers such processes and describes resulting sediment accumulation. Further modelling work would be required to better constrain erosion/deposition cycles on a seasonal time scale.

Regarding the objectives of the MICROBENT programme, this present investigation on sedimentation processes at sites C4 and C5 have two main implications. First, sedimentation accumulation appears rather stable over few decades for both sites, which is a positive result for joint studies. But, there are clear seasonal changes of bioturbation intensity which could influence element distributions. Indeed such variations are likely to mix temporarily deepest sediment layers and thus to remobilize chemical species. Modelling of reactive species must take into account these seasonal variations of bioturbation rates, especially for site $\mathrm{C} 5$, to produce accurate flux estimates.

\section{Acknowledgements}

This work is supported by the PNEC-ART1 MICROBENT programme, the CNRS, the University of Bordeaux I and the CEA. We are grateful to the COM diving team (R. Graille, B. de Ligondès, F. Zuberer) for their skilled work in the field, and to G. Sarazin for some diving help. The authors thank the Ifremer for logistic support through their lab space and research boat. We thank J.-L. Guillou and the crew of the Chlamys for its assistance at sea. Constructive comments of the three reviewers made it possible to significantly improve the manuscript. This is EPOC contribution no. 1629.

\section{References}

Aller, R.C., Cochran, J.K., 1976. ${ }^{234} \mathrm{Th} /{ }^{238} \mathrm{U}$ disequilibrium in near-shore sediment: particle reworking and diagenetic timescales. Earth and Planetary Science Letters 29, 37-50.

Appleby, P.G., Oldfield, F., 1992. Application of lead-210 to sedimentation studies. In: Ivanovich, M., Harmon, R.S. (Eds.), Uranium-Series Disequilibrium: Application to Earth, Marine, and Environmental Sciences, second ed. Clarendon Press, Oxford, pp. 731-778.

Chapelle, A., Menesguen, A., Deslous-Paoli, J.M., Souchu, P., Mazouni, N., Vaquer, A., Millet, B., 2000. Modelling nitrogen, primary production and oxygen in a Mediterranean lagoon. Impact of oysters farming and inputs from the watershed. Ecological Modelling 127, 161-181.

Cochran, J.K., Aller, R.C., 1979. Particle reworking in sediments from the New York Bight Apex: evidence from ${ }^{234} \mathrm{Th} /{ }^{238} \mathrm{U}$ disequilibrium. Estuarine, Coastal and Marine Science 9, 739-747.

Dedieu, K., Rabouille, C., Thouzeau, G., Mesnage, V., Chauvaud, L., Clavier, J., Jean, F., Ogier, S., 2007. Benthic $\mathrm{O}_{2}$ distribution and dynamics in a Mediterranean lagoon (Thau, France): An in situ microelectrode study. Estuarine, Coastal and Shelf Science 72 (3), 393-405.

DeMaster, D.J., McKee, B.A., Nittrouer, C.A., Jiangchu, Q., Guodong, C., 1985. Rates of sediment accumulation and particle reworking based on radiochemical measurements from continental shelf deposits in the East China Sea. Continental Shelf Research 4, 143-158.

Duport, E., Gilbert, F., Poggiale, J.-C., Stora, G., 2007. Benthic macrofauna and sediment reworking quantification in contrasted environments in the Thau Lagoon. Estuarine, Coastal and Shelf Science 72 (3), 522-533.

Fuller, C.C., van Geen, A., Baskaran, M., Anima, R., 1999. Sediment chronology in San Francisco Bay, California, defined by ${ }^{210} \mathrm{~Pb},{ }^{234} \mathrm{Th},{ }^{137} \mathrm{Cs}$ and ${ }^{239,240} \mathrm{Pu}$. Marine Chemistry 64, 7-27.

Gangnery, A., Bacher, C., Buestel, D., 2001. Assessing the production and the impact of cultivated oysters in the Thau lagoon (Mediterranee, France) with a population dynamics model. Canadian Journal of Fisheries and Aquatic Sciences 58, 1012-1020.

Jouanneau, J.-M., Weber, O., Drago, T., Rodrigues, A., Oliveira, A., Dias, J.A., Garcia, C., Schmidt, S., Reyss, J.-L., 2002. Present day sedimentation and sedimentary budgets on the northern Iberian shelf. Progress in Oceanography 52, 261-275.

Koide, M., Bruland, K.W., Goldberg, E.D., 1973. Th-228/Th-232 and Pb-210 geochronologies in marine and lake sediments. Geochimica et Cosmochimica Acta 37, 1171-1187.

Krishnaswamy, S., Lal, D., Martin, J.-M., Meybeck, M., 1971. Geochronology of lake sediments. Earth and Planetary Science Letters 11, 407-414.

Labonne, M., Othman, D.B., Luck, J.-M., 2001. Pb isotopes in mussels as tracers of metal sources and water movements on a lagoon (Thau Basin, S. France). Chemical Geology 181, 181-191.

Lecroart, P., Schmidt, S., Jouanneau, J.-M., 2007. Numerical estimation of the error of the biodiffusion coefficient in coastal sediments. Estuarine, Coastal and Shelf Science 72 (3), 543-552.

Migeon, S., Weber, O., Faugères, J.C., Saint Paul, J., 1998. A new X-ray imaging system for core analysis. Geomarine Letters 18, 251-255.

Millot, B., 1989. Fonctionnement hydrodynamique du basin de Thau. Validation écologique d'un modèle numérique de circulation (programme Ecothau). Oceanologica Acta 12, 37-41.

Monna, F., Lancelot, J., Bernat, M., Mercadier, H., 1997. Taux de sédimentation dans l'étang de Thau à partir des données géochronologiques, géochimiques et des repères stratigraphiques. Oceanologica Acta 20, 627-638.

Olsen, C.R., Larsen, I.L., Lowry, P.D., Cutshall, N.H., Nichols, M.M., 1986. Geochemistry and deposition of ${ }^{7} \mathrm{Be}$ in river-estuarine and coastal waters. Journal of Geophysical Research 91, 896-908.

Pena, G., 1989. Sels nutritifs et micropolluants métalliques dans un écosystème lagunaire: l'étang de Thau. Ph D. Université de Montpellier-II, France, $143 \mathrm{pp}$. 
Plus, M., Chapelle, A., Lazure, P., Auby, I., Levavasseur, G., Verlaque, M., Belsher, T., Deslous-Paoli, J.-M., Zaldívar, J.-M., Murray, C.N., 2003. Modelling of oxygen and nitrogen cycling as a function of macrophyte community in the Thau lagoon. Continental Shelf Research 23, 1877-1898.

Rabouille, C., Prevot, F., Amouroux, D., Anschutz, P., Gilbert, F., Cossa, D. 2007. Biogeochemical and contaminant cycling in sediments from a human-impacted coastal lagoon - Introduction and summary. Estuarine, Coastal and Shelf Science 72 (3), 387-392.

Radakovitch, O., Charmasson, S., Arnaud, M., Buisset, P., 1999. ${ }^{210} \mathrm{~Pb}$ and Caesium accumulation in the Rhône Delta sediments. Estuarine, Coastal and Shelf Science 48, 77-92.

Robbins, J., Edgington, D.N., 1975. Determination of recent sedimentation rates in Lake Michigan using ${ }^{210} \mathrm{~Pb}$ and ${ }^{137} \mathrm{Cs}$. Geochimica et Cosmochimica Acta 39, 285-304.
Schmidt, S., 2004. Investigation of dissolved uranium content in the watershed of the Seine River (France). Journal of Environmental Radioactivity 78, 1-10.

Schmidt, S., van Weering, Tj.E., de Stigter, H.C., 2001. Enhanced short-term deposition within the Nazare Canyon, North-East Atlantic. Marine Geology $173,55-67$.

Schmidt, S., van Weering, Tj.E., Reyss, J.-L., van Beek, P., 2002. Seasonal deposition and reworking at the sediment-water interface on the northwestern Iberian Margin. Progress in Oceanography 52, 331-348.

Sharma, P., Gardner, L.R., Moore, W.S., Bollinger, M.S., 1987. Sedimentation and bioturbation in a salt marsh as revealed by ${ }^{210} \mathrm{~Pb},{ }^{137} \mathrm{Cs}$, and ${ }^{7} \mathrm{Be}$ studies. Limnology and Oceanography 32, 313-326.

Widdows, J., Blauw, A., Heip, C.H.R., Herman, P.M.J., Lucas, C.H., Middelburg, J.J., Schmidt, S., Brinsley, M.D., Twisk, F., Verbeek, H., 2004. Role of physical and biological processes in sediment dynamics. Marine Ecology Progress Series 274, 41-56. 